\title{
Private landowners' preferences for trading forest landscape and recreational values: A choice experiment application in Kuusamo, Finland
}

\author{
Liisa Tyrväinen $^{\mathrm{a}, *}$, Erkki Mäntymaa ${ }^{\mathrm{b}}$, Artti Juutinen ${ }^{\mathrm{b}, \mathrm{c}}$, Mikko Kurttila ${ }^{\mathrm{d}}$, Ville Ovaskainen ${ }^{\mathrm{a}}$ \\ ${ }^{a}$ Natural Resources Institute Finland (Luke), Latokartanonkaari 9, FI-00790, Helsinki, Finland \\ ${ }^{\mathrm{b}}$ Natural Resources Institute Finland (Luke), Paavo Havaksen tie 3, FI-90014, Oulu, Finland \\ c Oulu Business School, University of Oulu, Pentti Kaiteran katu 1, FI-90014, Oulu, Finland \\ ${ }^{\mathrm{d}}$ Natural Resources Institute Finland (Luke), Yliopistokatu 6, FI-80100, Joensuu, Finland
}

\section{A R T I C L E I N F O}

\section{JEL classification:}

Q23

Q26

Q51

Z38

Keywords:

Choice experiment

Nature-based tourism

Payments for ecosystem services

Private forests

Willingness to accept compensation

Random parameters logit

\begin{abstract}
A B S T R A C T
Although nature-based tourism is increasingly recognized in forest strategies, economic incentives for private landowners supporting the production of amenity values are largely lacking. This study focused on possibilities to enhance the scenic and recreational values of private forests for nature-based tourism in Finland. More specifically, we studied forest owners' attitudes towards - and willingness to participate in - a Payments for Ecosystem Services (PES) initiative called Landscape and Recreation Value Trade. We also investigated the acceptability of forest management alternatives sustaining landscape qualities, the relative importance of different features of Landscape and Recreation Value Trade for landowners, and the magnitude of overall compensation claims of alternative Landscape and Recreation Value Trade models. A choice experiment survey was conducted in Kuusamo, a popular nature-based tourism destination, located in northeastern Finland. The results show that several forest owners were interested in the suggested scheme if economic losses were to be compensated. The landowners' preferences for Landscape and Recreation Value Trade were somewhat heterogeneous, suggesting that private forest owners in Kuusamo have rather diverse motivations and objectives for their ownership. Owners who stated to have scenic landscapes on their land, and those living outside Kuusamo area, were more willing to join in the suggested mechanism. In general, landowners' willingness to participate was strongly dependent on the amount of compensation as well as on other terms of the contract, such as the duration and severity of harvesting restrictions. The largest marginal compensation claims were related to long contract durations and the stringent "no harvesting at all" restriction. Given the heterogeneity in landowners' preferences, a Landscape and Recreation Value Trade model, offering flexibility to join the system, is needed to attract landowners of forests in hotspot locations for tourism that would help in designing a cost-efficient model for practical application.
\end{abstract}

\section{Introduction}

Forests produce multiple benefits, such as biomass and timber, as well as many non-material values that are increasingly in demand by European societies (e.g. Winkel, 2017). The wide range of non-material benefits includes various opportunities, for example, for outdoor recreation and tourism, nature, and aesthetic experiences contributing to human health and well-being (Millennium Ecosystem Assessment, 2005). These non-material benefits typically have characteristics of public goods, and therefore, their provision is challenging. This paper analyses possibilities to sustain and increase recreational benefits in private forests for nature-based tourism (NBT).

NBT is already an important business and has growth potential in many countries and regions in Europe (e.g. Bell et al., 2008; Roadmap for tourism, 2015). NBT companies are often small and cooperate with other companies, resource users, and resource owners - namely, landowners (Fredman and Tyrväinen, 2010). Some entrepreneurs provide their services in public forests, but in some areas across Europe, their businesses are based on the utilization of privately owned forests. This use can be justified by prevailing practices, such as Everyman's Right, enabling free access to all undeveloped lands (Kaltenborn et al., 2001; Sandell and Fredman, 2010), or by specific contracts between

\footnotetext{
* Corresponding author.

E-mail addresses: liisa.tyrvainen@luke.fi (L. Tyrväinen), erkki.mantymaa@luke.fi (E. Mäntymaa), artti.juutinen@luke.fi (A. Juutinen), mikko.kurttila@luke.fi (M. Kurttila), ville.t.ovaskainen@gmail.com (V. Ovaskainen).
} 
landowners and entrepreneurs. Although the tourism business has been included as an important target in some forest strategies (e.g. Finnish Bioeconomy Strategy, 2014; Swedish Research and Innovation Strategy, 2012), economic incentives for private landowners supporting the production of amenity values are largely lacking. In Finland, for example, most state subsidies for private forest owners target the enhancement of timber production (Hänninen et al., 2017). In addition, Finland has implemented the Forest Biodiversity Program (METSO) to enhance conservation on private lands on a voluntary basis since 2008. The criteria for choosing eligible sites do not include scenic or recreation values as a core criteria (Juutinen and Ollikainen, 2010; Juutinen et al., 2013), which has led to choice of sites that are often difficult to reach for recreationists and tourists. Moreover, these areas are inadequate to maintain the natural appearance of landscapes in private forests used primarily for wood production.

NBT builds on attractive natural beauty and nature-based experiences and activities, and is therefore highly dependent on the quality of the natural environment (Tyrväinen et al., 2008; Margaryan, 2016). Intensive wood (biomass) production and forest management (e.g. clear cuts, shortened rotation cycles, and large management units) have negative impacts on nature experience and forest landscape quality, as well as the business opportunities of NBT companies. In contrast, people typically appreciate mature forests with good visibility, some undergrowth, and a green field layer with no strong visible signs of forest management (e.g., Gundersen and Frivold, 2008; Tyrväinen et al., 2017). Consequently, small-scale forest management or continuous cover forestry, maintaining forested landscapes with natural appearances, are needed areas with high or growing tourism and recreational use. Small-scale forest management practices used to enhance recreational benefits have been shown to be highly valued by citizens (Juutinen et al., 2014).

The EU forest-related policies are complex and represented by several sectoral policies, but have a relatively small effect on guiding the use of forests at the national level (Aggestam et al., 2017). Biodiversity protection, for example, is partially guided by EU policies - in particular, the Habitats Directive (Council Directive, 2020), and is mainly applied by establishing networks of NATURA2000 sites, leaving biodiversity protection outside protected areas regulated mainly by national policies. Landscape protection, however, has less emphasis in both EU and national policies. It is excluded in nature conservation legislation, and the topic is addressed only at a general level in the European Landscape Convention (Council of Europe, 2012). The national legislation targeted at maintaining forested landscapes is also often missing or rather limited.

Payments for Ecosystem Services (PES) policies compensate individuals or communities for undertaking actions that increase the provision of ecosystem services (Jack et al., 2008). The PES approach and market-based instruments have recently received increased attention as a means of enhancing the provision of ecosystem services (e.g. Wunder, 2007; Lindhjem and Mitani, 2012; Thorsen et al., 2014; Vedel et al., 2015a). In Finland, a PES scheme called Landscape and Recreation Value Trade (LRVT) has been proposed, in which forest owners would be compensated for voluntarily enhancing the provision of landscape and recreational values in their own forests (e.g. Tyrväinen et al., 2014; Tikkanen et al., 2017). The funding for the mechanism has been suggested to be collected from the visitors and/or tourism entrepreneurs of the area, and, if available, it can be combined with public funding. A recent choice experiment study targeted to visitors in the Ruka-Kuusamo tourism area suggested that there is a significant demand for - and willingness to pay for - forest landscape management improvements, especially for improvements both in the quality of the landscape and the biodiversity (Tyrväinen et al., 2014; Mäntymaa et al., 2018b). Given the identified demand for local forest amenities, it is important to understand the supply side in depth, that is, the landowners' willingness to commit to voluntarily enhancing forest environments for tourism and recreation. Moreover, in the design of an acceptable PES model, it is important to assess landowners' attitudes towards, and acceptable criteria of, such mechanisms.

Previous research results show that private forest owners have diverse motivations, attitudes, and goals linked to their ownership (Kuuluvainen et al., 1996; Boon et al., 2004; Majumdar et al., 2008; Häyrinen, 2019). For example, $37 \%$ of private forest owners in the Southern Black Forest in Germany are motivated by lifestyles that enable the enjoyment of experiencing nature rather than economic considerations (Bieling, 2004). In England, up to $47 \%$ of woodland owners are driven by concerns for amenity values, such as public and private recreation, scenery, or wildlife watching (Urquhart and Courtney, 2011). At least 17 studies in Europe have identified forest owners that are influenced by amenity values (Urquhart et al., 2012). The variety of goals has increased due to urbanization, changing values in society, and forest owners' decreased dependence on forest-based incomes (Dominguez and Shannon, 2011; Karppinen and Korhonen, 2013). Increased appreciation of amenity values and diversified ownership motives in Finland (e.g. Häyrinen, 2019) also suggest that forest owners may be more willing to adopt new instruments to provide amenity benefits.

Finland has 737,000 forest owners managing some 347,000 forest holdings, exceeding 2 ha of forestland (Finnish statistical yearbook of forestry, 2014). Leppänen (2010) have grouped forest owners into multi-objective owners, recreationists, self-employed owners (i.e. self-active forest owners also prioritizing labour income from forests), investors, and indifferent owners. Increased shares of multi-objective or amenity-value-oriented forest owners have been recognized in recent studies (e.g., Hänninen et al., 2011; Valkeapää and Karppinen, 2013). Moreover, Häyrinen et al. (2017) found that non-industrial private forest owners were emphasizing future value creation based more largely on forest ecosystem services. Thus, new possibilities may emerge for the provision of forest-based recreational services, cooperation with NBT, and increasing value-added wood products.

Research on private forest owners' willingness to engage in producing amenity benefits with PES schemes has focused largely on biodiversity conservation efforts (e.g., Horne, 2006; Mäntymaa et al., 2009; Lindhjem and Mitani, 2012; Vedel et al., 2015a). Horne (2006), for example, examined the factors that affect the acceptability of biodiversity conservation contracts among private forest owners. The studied factors included the initiator of the contract, restrictions on forest use, compensation, duration of contract, and cancellation policy. These results give valuable knowledge about forest owners' preferences for contract-based mechanisms, but the results of biodiversity studies may not be generalized to landscape protection. There is also growing research on how to enhance landscape and recreational values (e.g. Campbell et al., 2014; Ovaskainen et al., 2014; Tikkanen et al., 2017; Mäntymaa et al., 2019). In a recent article by Mäntymaa et al. (2018a), the forest owners' preferences for LRVT were examined by the attribute-based contingent valuation method. The study focused on the owners' participation rates and how the compensation claims differ between segments of forest owners in the Ruka-Kuusamo area in Finland. The study included only two attributes for contract terms and conditions: harvest restrictions and method of making contracts (competitive tendering versus private negotiations).

In the present article, we add to the previous research by analyzing in greater depth the acceptable design of the PES model for forest owners by using a choice experiment with several attributes for contract terms and conditions, including harvest restrictions, size of the contracted forest area of the property, length of new hiking and skiing routes, and duration of contract. It is highly important to identify and be aware of forest owners' preferences for the attributes of alternative mechanism designs when developing a new PES system, such as the LRVT, to enhance the provision of landscape and recreational values in privately owned forests. The main aims of the article are as follows:

(i) To study the preconditions for forest owners' participation in the LRVT. We investigate, first, the acceptability of alternative forest 
management regimes that sustain forest landscape qualities, and second, forest owners' attitudes towards using their own forests for tourism and willingness to join the proposed LRVT system.

(ii) To explore the relative importance (and significance) of different attributes of LRVT in terms of marginal willingness-to-accept (WTA), and to explain the heterogeneity in forest owners' preferences.

(iii) To assess the magnitude of overall compensation claims related to alternative LRVT contracts using scenario analysis.

\section{Materials and methods}

\subsection{Case study: the Ruka-Kuusamo tourism area}

Kuusamo, a town and municipality with the acreage of 5809 square kilometers, is located in northeastern Finland in an area rich in hills and fells. The population density is low (3.2 inhabitants per square $\mathrm{km}$ ), with $70 \%$ living in the town center, and the rest living in sparsely populated, rural areas. About two-thirds of employed people work in services such as tourism, one-sixth work in processing industries, and about $10 \%$ work in agriculture, forestry, and reindeer husbandry. As much as $84 \%$ of the municipality's total land area is forested, and $82 \%$ of the forest has non-industrial private ownership (National Forest Inventory 9, 2016).

Tourism plays a significant role in the region's economy. One of the largest ski resorts in Finland, Ruka, is situated in Kuusamo. Annually, around 1 million tourists visit Kuusamo, yielding a total revenue of over 90 million euros and providing full-time employment to over 800 people. The annual number of registered overnight stays in hotels with over 20 beds (excluding stays in one's own home or rental cottages) is 490,000 . About $23 \%$ of visitors who stay overnight are international tourists. The key tourism activities include downhill and cross-country skiing, snowshoeing, snowmobiling, and husky safaris, as well as hiking, cycling, canoeing, and the observation of birds and other boreal species. The accommodation capacity is 12,000 beds, including hotel rooms and holiday homes, as well as 6900 holiday apartments and cottages (Facts about Ruka and Kuusamo, 2017). The area's strategic goals for developing the tourism sector include increased year-round tourism, increased international tourism, and an increased occupancy rate of accommodation sites.

\subsection{Questionnaire, data collection, and sample representativeness}

The basic premise in valuing non-market forest goods with the choice experiment (CE) method is that people have preferences for certain goods, and any good can be described through its characteristics, that is, as a bundle of specific attributes. In economic valuation, it is assumed that people are willing and able to trade-off money for these attributes, and a monetary price attribute is therefore also included. In the $\mathrm{CE}$, different attributes are traded off in the process of value elicitation, so that a decrease in one attribute may be compensated by an increase in another attribute. The CE is a tool for revealing the respondents' valuations of defined environmental goods, the quality of which may vary, as described through levels of attributes. The analysis of respondents' choices provides resource managers and policy makers with detailed information about public preferences for various levels of the quality or quantity of, for example, forest goods and services produced. As a multiattribute method, allowing the simultaneous valuation of several attributes, the CE is particularly suitable for the purpose of an integrated valuation of several key forest externalities.

The questionnaire consisted of six sections. The first section dealt with the main features of the forest property, including information about the size of the forest area, availability of up-to-date forest management plan, timber sales, and recent harvesting or other forest management activities. The second section inquired into forest owners' attitudes towards different forest management goals and the integration
Table 1

Attributes and levels used in the choice experiment.

\begin{tabular}{ll}
\hline Attributes & Levels (variable name in choice analysis) \\
\hline & No restrictions* \\
& No clear-cutting (CUT1) \\
Harvesting restrictions & No regeneration cuttings (CUT2) \\
& No harvesting at all (CUT3) \\
& $0^{*}, 5,10$ or $20 \%$ of the forest area of the \\
Size of restrictions & property (SIZE) \\
Length of new hiking and skiing & $0^{*}, 500$ or 1000 meters (ROUT) \\
routes & $0^{*}, 5,10$ or 20 years (DUR) \\
Duration of contract & $€ 0^{*}, € 30, € 60, € 120, € 180, € 240$ or $€ 300$ \\
Amount of compensation: & (COMP) \\
$€ /$ hectare/year &
\end{tabular}

* The level associated with the no-contract alternative in a choice card.

of environmental goals in forest management in the Ruka-Kuusamo tourism area. The third section inquired into respondents' ownership objectives and related management targets for their own forest holdings. The fourth section investigated forest owners' experiences, especially familiarity with and participation in different national policy programs enhancing the environmental values of forests. The fifth section, containing the $\mathrm{CE}$, asked specific questions about the content and terms of the LRVT scheme that the forest owners would be willing to accept.

In the CE, the respondents were asked to imagine that the LRVT would be initiated in the Ruka-Kuusamo area. They were shown choice cards where the attributes of a trading contract, that is, the type and size of harvesting restrictions, length of outdoor routes, duration of contract, and compensation levels ( $€$ /hectare/year), varied randomly (Table 1 ). Each card contained two alternative LRVT contracts and an opt-out option (i.e. no-contract alternative), and respondents were prompted to choose one alternative in each card. Finally, the questionnaire inquired into the socio-economic information of the respondents. The questionnaire was developed through several versions and was commented on by both researchers and stakeholders in the target area, that is, the Forest Management Association Kuusamo.

Given the attributes and their levels, a full factorial design would require 864 choice sets, so a Bayesian efficient design was generated by by NGene 1.0.2. (ChoiceMetrics, 2010). The final design had 24 choice cards divided into 4 blocks, resulting in 6 choice cards to be answered by each respondent. The D-error at the generation stage was 0.000231 .

The population of the survey consisted of private forest owners within the borders of the Kuusamo municipality. Thus, the owners could live elsewhere in Finland or even abroad. The sample of owners was drawn from the register administered by the Kuusamo Forest Management Association, in which information about all people owning more than 7 ha of forest in the municipality is recorded.

The total sample of the survey was 1355 persons, consisting of two sub-samples. First, in the core of the Ruka-Kuusamo tourism area, where most of the outdoor activities and accommodation options, like hotels, apartments, and cottages, are located, all forest owners (about 1000 persons) were included in the sample. Second, in the rest of the municipality there are several single tourism firms located further away from the core tourism area. From this larger area, a sub-sample of people owning forest around these firms, about 350 individuals, were selected into the survey. As the number of owners in the register is about 3900 , our total sample comprised one-third of this. This kind of sampling is not random in the statistical sense, but will most likely give a representative picture of forest owners' interests in the enhancement of quality of landscape and the use of the LRVT mechanism in the most relevant area for the study.

The survey was implemented as a conventional postal survey. The main reason for not conducting an Internet survey was that the average age of forest owners in Finland is rather high (in this region, 62 years of age). As a consequence, forest owners are not very used to or keen to respond to surveys through the Internet. In March 2012, the 
Table 2

Socio-demographic characteristics of the Ruka-Kuusamo respondents and forest owners in the Northern Ostrobothnia region.

\begin{tabular}{|c|c|c|c|}
\hline Variable & Category & Kuusamo & $\begin{array}{l}\text { Northern } \\
\text { Ostrobothnia }\end{array}$ \\
\hline Sample size ${ }^{\mathrm{b}}$ & & 464 & \\
\hline \multirow[t]{3}{*}{ Gender (\%) } & Female & 18.9 & 28 \\
\hline & Male & 81.1 & 72 \\
\hline & All & 100 & 100 \\
\hline \multirow[t]{7}{*}{ Age (ye $\left.{ }^{a} r s, \%\right)$} & Below 45 & 10.4 & 13 \\
\hline & $45-54$ & 22.0 & 18 \\
\hline & $55-64$ & 28.4 & 31 \\
\hline & $65-74$ & 27.6 & 22 \\
\hline & 75 or above & 11.6 & 15 \\
\hline & All & 100 & 100 \\
\hline & Mean & 60.2 & 60 \\
\hline \multirow[t]{6}{*}{ Occupational status } & Wage-earners & 33.1 & 35 \\
\hline & Farmers & 5.7 & 8 \\
\hline & Entrepreneurs & 11.3 & 8 \\
\hline & Retired & 47.8 & 48 \\
\hline & Others & 2.2 & 3 \\
\hline & All & 100 & 100 \\
\hline $\begin{array}{l}\text { Area of forest property } \\
\text { (ha) }\end{array}$ & Mean & 62.5 & 39 \\
\hline
\end{tabular}

a Source: Hänninen et al. (2011).

b The number of observations varies between questions.

questionnaires were sent to the forest owners chosen in the sample, followed by reminder cards after two weeks, and another full questionnaires after an additional three weeks for those who had not yet responded. The final number of completed responses was 471 , meaning that the response rate was $35.3 \%$.

As there is no census information available regarding Finnish forest owners, we provide the results from a regularly conducted and extensive Finnish forest owner survey, the most recent edition of which covers the period of 2007-2009 (see Hänninen et al., 2011), to assess the representativeness of our data. We compared some socio-economic characteristics between the respondents to the Ruka-Kuusamo survey and the forest ownership structure of the forestry center region, Northern
Ostrobothnia, to which Kuusamo belongs (Table 2). The respondents of the Ruka-Kuusamo data are more often male than those in the national study. The average age and the distribution of the occupational status of the respondents are about the same in the both studies. The percentage of retired people both among the respondents and in the region is large, reflecting the high average age of forest owners. The acreage of forest property, however, is larger in the Ruka-Kuusamo study than in the whole Northern Ostrobothnia region, specifically 62.5 vs. 39 ha. This suggests that this study more often reached those who own larger-than-average areas of forests and probably also those who are more interested in promoting both forestry and tourism. Therefore, our results may not necessarily represent forest owners' views in the whole region.

\subsection{Econometric specification and welfare measurement}

We use the random parameters logit (RPL) model, also called the mixed logit (MXL) model, to analyze our choice experiment data (Train, 2009). The RPL is particularly fit for dealing with preference heterogeneity at the individual level across all attributes (Hynes et al., 2008). The RPL can be derived from a random utility model assuming that respondents maximize their utility through their choices over the alternatives presented in a series of choice cards. In the model formulation, the utility to an individual $i$ from selecting an alternative $j$ in a choice situation $t$ described by $K$ observed attributes $x_{i j t}=\left\{x_{i j t}^{1}, \ldots, x_{i j t}^{K}\right\}$ is defined by the formula:

$U_{i j t}=\alpha_{i j}+\boldsymbol{\beta}_{i k}^{\prime} \boldsymbol{x}_{i j t}+\varepsilon_{i j t}$,

where $\alpha_{i j}$ is an alternative-specific constant, $\boldsymbol{\beta}_{i k}^{\prime}$ is a vector of attribute weights, and $\varepsilon_{i j t}$ is the i.i.d. extreme value idiosyncratic error. The probability for such a choice is then defined as:

$$
\operatorname{Pr}\left(y_{i t}=j\right)=\frac{\exp \left(\alpha_{i j}+\boldsymbol{\beta}_{i k}^{\prime} \boldsymbol{x}_{i j t}\right)}{\sum_{q=1}^{J} \exp \left(\alpha_{i q}+\boldsymbol{\beta}_{i k}^{\prime} \boldsymbol{x}_{i q t}\right)} .
$$

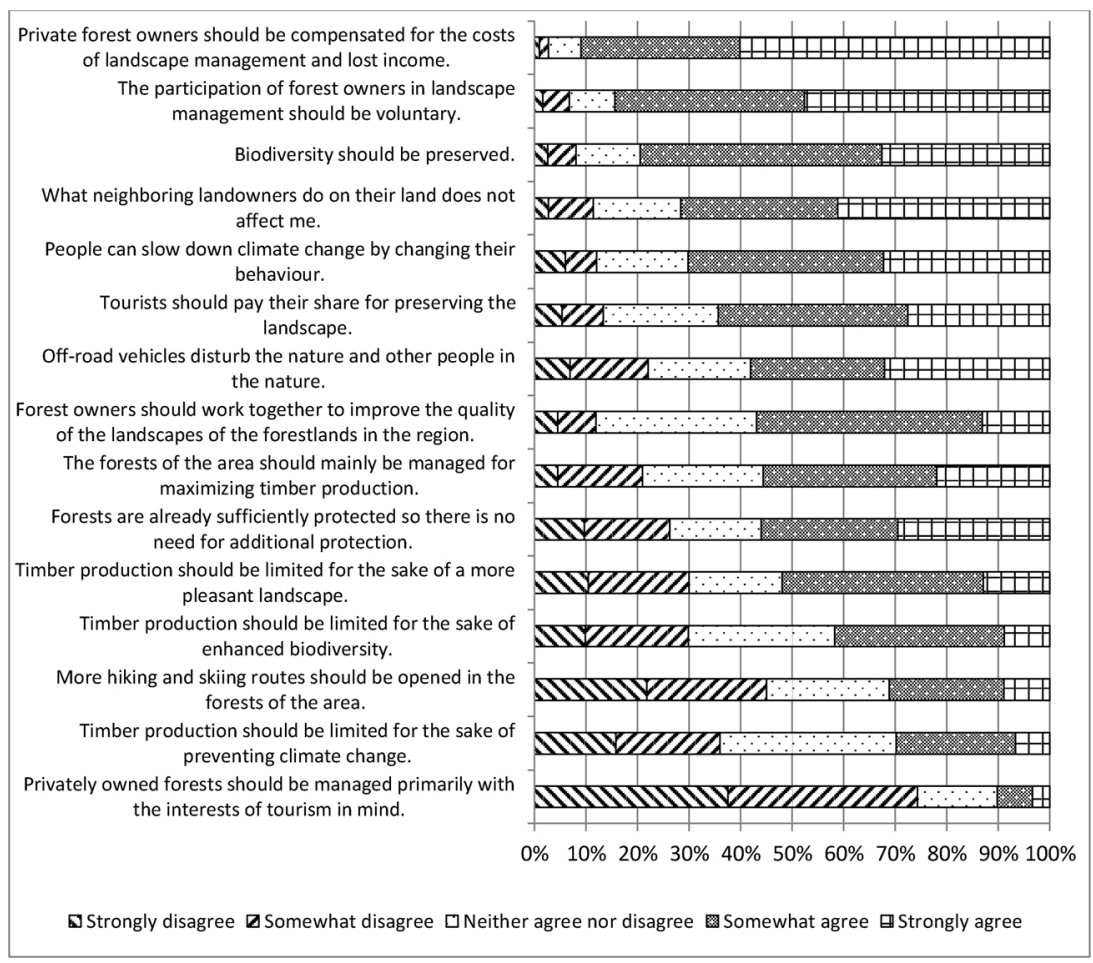

Fig. 1. Forest owners' attitudes towards environmental services of forests: agreements with statements. 


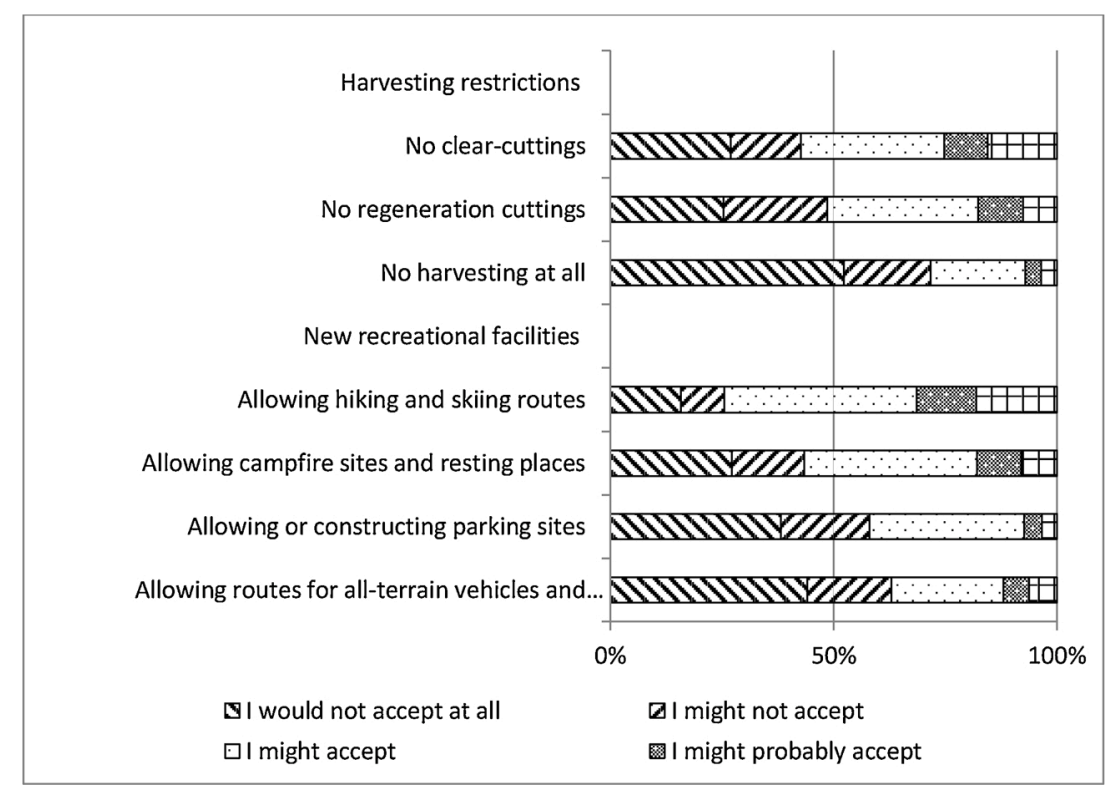

Fig. 2. The assessments of acceptability of measures required by the LRVT contract during the contract period in the delineated areas of special scenic importance.

In the RPL model, the individual-specific preference parameters $\beta_{i k}^{\prime}$ and choice-specific constants $\alpha_{i j}$ are not fixed for all respondents, but vary around means and are modelled as follows:

$\beta_{i k}=\beta_{k}+\boldsymbol{\delta}_{k}^{\prime} z_{i}+\vartheta_{i k}$

$\alpha_{i j}=\alpha_{j}+\boldsymbol{\delta}_{j}^{\prime} z_{i}+\vartheta_{i j}$

where $\alpha_{j}$ is an alternative-specific constant, and $\vartheta_{i j}$ is normally distributed (with zero mean) heterogeneity of the choice-specific constants; $\beta_{k}$ is the population mean of $k$-attribute coefficient, and $\vartheta_{i k}$ is the individual specific heterogeneity of a taste parameter. Notice the observed attributes include a price attribute and non-price attributes. In this study, the former is a payment made to the landowner to compensate for the loss caused by landscape-friendly forest management. For the associated taste parameters, we assume that the non-price parameters follow the normal distribution with zero mean. Correlation among the random parameters is not allowed. The price parameter is assumed to be fixed, that is, the marginal utility of money is assumed to be constant over the population, to obtain reasonable distributions for the WTA estimates. The means of the parameter distributions of $\alpha_{i k}$ and $\beta_{i k}$ are also allowed to be heterogeneous with respondents' individual characteristics $z_{i}$, which enter the formulas for taste parameters and alternative-specific constants with vectors of weights $\delta_{k}$ and $\delta_{j}$, respectively. In this study, we examine individual characteristics that explain heterogeneous preferences of the alternative-specific constant, a dummy variable which is equal to one for the opt-out option.

Following welfare economics (Hanemann, 1982), we use marginal WTA measures to assess the relative importance of the non-price attributes. The marginal WTA is computed as:

$\mathrm{WTA}_{\mathrm{k}}=-\frac{\widehat{\beta}_{\mathrm{k}}}{\widehat{\beta}_{\mathrm{p}}}$,

where $\widehat{\beta}_{\mathrm{k}}$ denotes the estimated parameter of attribute $k$, and $\widehat{\beta}_{\mathrm{p}}$ is the estimated parameter of the price attribute. In addition, we use the compensation variation (CV) formula to assess the welfare impacts of alternative contact designs and associated compensation requirements as follows:
$\mathrm{CV}=-\frac{1}{\widehat{\beta}_{\mathrm{p}}}\left(V_{1}-V_{0}\right)$,

where $V_{0}$ and $V_{1}$ are the utility expressions for the base and altered contract designs, respectively. In this study, the base case is no contact, that is, $V_{0}$ includes only the alternative-specific constant. By contrast, $V_{1}$ includes parameters of observed non-price attributes that describe a particular contact for the LVTR.

\section{Results}

\subsection{Attitudes towards use of forests for nature-based tourism and LRVT}

Forest owners' attitudes towards the environmental services of forests were examined by asking to what extent they agree with a set of statements (Fig. 1). The statement with the strongest support was "Private forest owners should be compensated for the costs of landscape management and lost income," with which over $90 \%$ of respondents somewhat agreed or strongly agreed. A vast majority of owners also agreed with "The participation of forest owners in landscape management should be voluntary" and "Biodiversity should be preserved." In addition, more than $70 \%$ of the respondents agreed that "What neighboring landowners do on their land does not affect me" and "People can slow down climate change by changing their behavior." The largest share of disagreement was given to the statements "Privately owned forests should be managed primarily with the interests of tourism in mind" (74.3 \% somewhat or strongly disagreed) and "More hiking and skiing routes should be opened in the forests of the area" (45.0\% disagreed).

Respondents owning forests within the Kuusamo municipality had rather positive attitudes towards the suggested mechanism, although the idea of LRVT was somewhat new for most respondents. Altogether, $43 \%$ of the respondents were very, moderately, or slightly interested in participation, and the rest were not very interested or interested at all. It must be noted that in inquiring about forest owners' interest in participating in LRVT, the description of the mechanism remained at the general level without specifying conditions or terms of contract in detail.

Before presenting the CE choice sets, we also asked the respondents to separately assess the acceptability of the conditions and the importance of the terms of the potential LRVT contract targeted to some scenically valuable areas of their forest properties. We used a five-point 


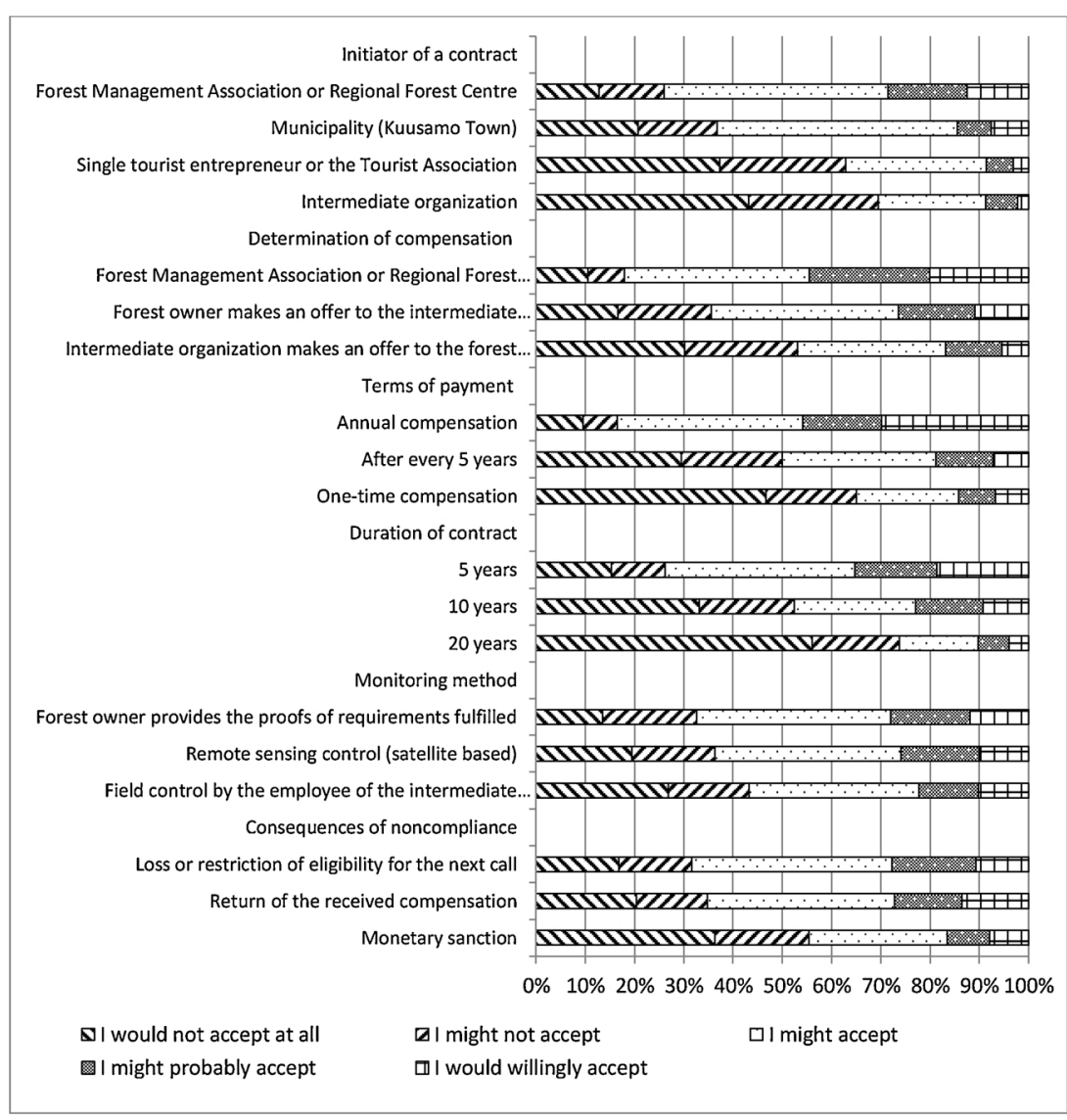

Fig. 3. The acceptability of practical arrangements in a LRVT contract.

Likert scale, from "I would not accept at all" to "I would willingly accept" (Fig. 2). Regarding potential harvesting restrictions, $42.7 \%$ of the respondents stated that the prohibition of clear-cuttings is "not at all acceptable" or "not acceptable." The respective results for not accepting the prohibition of all regeneration cuttings is $48.6 \%$, and the prohibition of all timber harvesting is $71.6 \%$. Moreover, regarding the acceptability of new recreational facilities, allowing construction of new hiking and skiing routes was mostly accepted (74.4\% might accept, would probably accept, or would willingly accept). Moreover, $56.6 \%$ of respondents would allow campfire sites and resting places, $41.9 \%$ would allow parking sites, and $37.0 \%$ would allow routes for all-terrain vehicles and snowmobiles. The high percentage of acceptability related to campfire sites and resting places may reflect the traditional use of forests for recreation in Kuusamo area, where these facilities are important not only for local use of forests - for example, for hunting and berry and mushroom picking - but also serve tourism purposes. The acceptability of routes for all-terrain vehicles and snowmobiles was low, which may result from the damages to seedlings they may cause if they are used outside the routes. Moreover, these vehicles perturb noise that disturbs both reindeer husbandry and recreational activities where silence in important quality of the environment.

Using the same Likert scale as in Fig. 2, we also asked the respondents to assess the acceptability of a large set of practical features of an LRVT contract, such as the initiator of a contract, determination of compensation, temporal distribution of payment (a lump sum, every 5 years, or annually), duration of a contract, monitoring method, and consequences of noncompliance (Fig. 3). With respect to the initiator of a contract, the most acceptable organization was the Kuusamo Forest Management Association or Regional Forest Centre $(74.0 \%$ might accept, might probably accept, or would willingly accept). The second most acceptable body was the municipality (Kuusamo Town, $63.3 \%$ ), and the third most acceptable was a single entrepreneur or the Ruka-
Kuusamo Tourist Association (37.1\%), which is an umbrella and a trustee organization for local tourism entrepreneurs. The least acceptable initiator was an "intermediate organization" (30.5\%), which was defined in an introductory text as a collaborative body between the forestry and tourism sectors.

Regarding the determination of the compensation to be paid for a possible contract, the alternative "Forest Management Association or Regional Forest Centre assesses the amount of compensation (loss of timber production and management work)" received the largest percentage of acceptance (82.1\%). Furthermore, almost two-thirds of respondents could accept a practice where the forest owner makes an offer to the intermediate organization $(64.5 \%)$, and less than half of respondents could accept a practice where an intermediate organization makes an offer to the forest owner $(46.9 \%)$. When asked about the temporal distribution of the compensation, the most popular was annual compensation ( $83.4 \%$ ), followed by compensation after every 5 years $(50.0 \%)$ and one-time compensation (35.0\%). Regarding the duration of a contract, the respondents clearly preferred shorter periods to longer ones ( 5 years $73.9 \%, 10$ years $47.6 \%, 20$ years $26.3 \%$ ). With respect to the preferred monitoring method of a contract, the assessments were more even: $67.4 \%$ of respondents accepted the statement "Forest owner provides the proofs of requirements fulfilled;" $63.7 \%$ accepted the statement "Remote sensing control (satellite based);" and $56.7 \%$ accepted the statement "Field control by the employee of the intermediate organization." Finally, we asked about the consequences of noncompliance and found the following order of acceptance: loss or restriction of eligibility for the next call (68.4\%); return of the received compensation (65.3\%); and monetary sanction (44.7\%).

\subsection{Choice analysis}

Consistent with economic theory, the COMP variable (amount of 
Table 3

Estimation results of the RPL model without interactions.

\begin{tabular}{|c|c|c|c|c|c|}
\hline Variable & Coefficient & Standard error & $\mathrm{P}$ value & \multicolumn{2}{|c|}{$95 \%$ confidence interval } \\
\hline \multicolumn{6}{|c|}{ Random parameters in utility functions } \\
\hline ASC & $* * * 1.09417$ & 0.37067 & 0.0032 & 0.36766 & 1.82067 \\
\hline CUT1 & $* * 0.65544$ & 0.27481 & 0.0171 & 0.11683 & 1.19405 \\
\hline CUT2 & -0.08275 & 0.28146 & 0.7688 & -0.63441 & 0.4689 \\
\hline CUT3 & $* * *-0.8229$ & 0.28461 & 0.0038 & -1.38073 & -0.26506 \\
\hline SIZE & $* * *-0.05074$ & 0.01143 & 0.0000 & -0.07314 & -0.02835 \\
\hline ROUT & -0.09711 & 0.11705 & 0.4067 & -0.32652 & 0.1323 \\
\hline DUR & $* * *-0.09455$ & 0.01358 & 0.0000 & -0.12118 & -0.06793 \\
\hline COMP & $* * * 0.00604$ & 0.0006 & 0.0000 & 0.00487 & 0.00721 \\
\hline \multicolumn{2}{|c|}{ Distns. of RPs. } & \multicolumn{4}{|c|}{ Std.Devs or limits of triangular } \\
\hline NsASC & $* * * 6.96387$ & 0.57602 & 0.0000 & 5.8349 & 8.09285 \\
\hline NsCUT1 & $* * 0.74587$ & 0.31494 & 0.0179 & 0.1286 & 1.36314 \\
\hline NsCUT2 & $* * * 0.94299$ & 0.26634 & 0.42098 & 0.0004 & 1.465 \\
\hline NsCUT3 & $* * * 1.72726$ & 0.23792 & 0.0000 & 1.26095 & 2.19356 \\
\hline NsSIZE & $* * * 0.06345$ & 0.01332 & 0.0000 & 0.03734 & 0.08957 \\
\hline NsROUT & $* * * 0.62847$ & 0.21292 & 0.0032 & 0.21116 & 1.04578 \\
\hline NsDUR & $* * * 0.10665$ & 0.01495 & 0.0000 & 0.07735 & 0.13596 \\
\hline CsCOMP & 0.0 & \multicolumn{4}{|c|}{ (Fixed Parameter) } \\
\hline \multicolumn{2}{|c|}{ Log likelihood function } & \multicolumn{4}{|l|}{-1486.46817} \\
\hline \multicolumn{2}{|l|}{ AIC } & \multicolumn{4}{|l|}{3002.9} \\
\hline \multicolumn{2}{|l|}{$\mathrm{AIC} / \mathrm{N}$} & \multicolumn{4}{|l|}{1.265} \\
\hline \multicolumn{2}{|c|}{$\mathrm{N}$ (observations) } & \multicolumn{4}{|l|}{2373} \\
\hline \multicolumn{2}{|c|}{ Panel (individuals) } & 416 & & & \\
\hline
\end{tabular}

$* * *$ Significant at the 0.01 level.

$*$ *Significant at the 0.05 level.

*Significant at the 0.10 level.

Table 4

Marginal WTAs.

\begin{tabular}{llll}
\hline Variable & WTA, $€ / \mathrm{h}^{\mathrm{a}} / \mathrm{yr}$ & \multicolumn{2}{l}{$95 \%$ confidence interval } \\
\hline ASC (no contract) & $* * *-181.2$ & -300.3 & -62.1 \\
CUT1 & $* *-108.5$ & -198.3 & -18.7 \\
CUT2 & 13.7 & -77.6 & 105.0 \\
CUT3 & $* * * 136.3$ & 42.5 & 230.0 \\
SIZE & $* * * 8.4^{\mathrm{a}}$ & 4.5 & 12.3 \\
ROUT & 16.1 & -21.5 & 53.6 \\
DUR & $* * * 15.7^{\mathrm{b}}$ & 11.2 & 20.1 \\
\hline
\end{tabular}

$* * *$ Significant at the 0.01 level.

$* *$ Significant at the 0.05 level.

*Significant at the 0.10 level.

a $€$ /percentage point/year.

b $€ /$ year.

monetary compensation) has a positive and significant coefficient, meaning that the higher the compensation for an LRVT contract, the higher the utility and probability of choosing the contract (Table 3, see the corresponding results of the RPL model that allows correlations among random parameters, available in the Appendix Table A1). The alternative-specific constant (ASC) reflects the utility associated with the status quo alternative, that is, a choice where a forest owner does not enter a contract within the mechanism. Thus, a positive and significant coefficient of ASC indicates that on average, the respondents derive higher utility from not joining in any LRVT scheme than subscribing to the suggested LRVT scheme that includes monetary compensation. In addition, the negative and significant coefficients show that an increase in the contracted proportion of the holdings' forest area (SIZE) or in the duration of the contract period (DUR) decreases the probability of accepting an LRVT contract. The same also holds for constructing $1000 \mathrm{~m}$ of hiking and skiing routes (ROUT), although the coefficient is not significant. Related to the cutting restrictions, the minus signs of no regeneration cuttings (CUT2) or no harvesting at all (CUT3) means that these cutting restrictions tend to decrease the probability of making a contract. Interestingly, the coefficient of the prohibition of clear-cuttings (CUT1), which was the mildest restriction, is positive and significant, indicating that this restriction would increase the possibility to make a contract. Note, however, that the coefficients of standard deviations of
Table 5

Individual-specific variables used to explain preference heterogeneity.

\begin{tabular}{|c|c|c|c|}
\hline Variable & Meaning, coding & Mean & $\begin{array}{l}\text { St. } \\
\text { dev. }\end{array}$ \\
\hline GEND & Respondent's gender, $0=$ female, $1=$ male & 0.81 & 0.39 \\
\hline AGE & Respondent's age, years & 61.2 & 12.53 \\
\hline KUUS & $\begin{array}{l}\text { Respondent living in Kuusamo municipality, } 0= \\
\text { no, } 1=\text { yes }\end{array}$ & 0.586 & 0.49 \\
\hline EDUC & $\begin{array}{l}\text { Respondent has a degree from university or } \\
\text { polytechnic, } 0=\text { no, } 1=\text { yes }\end{array}$ & 0.373 & 0.48 \\
\hline INHER & Inherited forest property, $0=$ no, $1=$ yes & 0.442 & 0.50 \\
\hline LANDSC & $\begin{array}{l}\text { Forest property includes scenic landscape, } 0=\text { no, } 1 \\
=\text { yes }\end{array}$ & 0.576 & 0.49 \\
\hline HINCOM & $\begin{array}{l}\text { Household net income lower than } 2000 € / \text { month, } \\
0=\text { no, } 1=\text { yes }\end{array}$ & 0.149 & 0.36 \\
\hline
\end{tabular}

Table 6

Estimation results of the RPL model with interactions.

\begin{tabular}{|c|c|c|c|c|c|}
\hline Variable & Coefficient & $\begin{array}{l}\text { Standard } \\
\text { error }\end{array}$ & $P$ value & \multicolumn{2}{|c|}{$\begin{array}{l}95 \% \text { confidence } \\
\text { interval }\end{array}$} \\
\hline \multicolumn{6}{|c|}{ Random parameters in utility functions } \\
\hline ASC & -0.24281 & 2.02651 & 0.9046 & -4.2147 & 3.72907 \\
\hline CUT1 & -0.03834 & 0.40277 & 0.9242 & -0.82776 & 0.75108 \\
\hline CUT2 & $*-0.64828$ & 0.38156 & 0.0893 & -1.39613 & 0.09957 \\
\hline CUT3 & $* * *-2.07275$ & 0.44314 & 0.0000 & -2.94129 & -1.20421 \\
\hline SIZE & $* * *-0.05382$ & 0.01596 & 0.0007 & -0.0851 & -0.02254 \\
\hline ROUT & -0.19057 & 0.18341 & 0.2988 & -0.55005 & 0.1689 \\
\hline DUR & $* * *-0.11889$ & 0.01808 & 0.0000 & -0.15432 & -0.08346 \\
\hline COMP & $* * * 0.00766$ & 0.00089 & 0.0000 & 0.00591 & 0.0094 \\
\hline \multicolumn{6}{|c|}{ Heterogeneity in mean } \\
\hline ASC:GEND & $* * *-4.32679$ & 1.24412 & 0.0005 & -6.76522 & -1.88835 \\
\hline ASC:AGE & $* 0.04570$ & 0.0265 & 0.0846 & -0.00623 & 0.09764 \\
\hline ASC:KUUS & $* * * 3.75593$ & 0.79632 & 0.0000 & 2.19517 & 5.31668 \\
\hline ASC:EDUC & $* * *-2.58447$ & 0.74546 & 0.0005 & -4.04554 & -1.1234 \\
\hline ASC:INHER & $* * * 3.01071$ & 0.78979 & 0.0001 & 1.46275 & 4.55868 \\
\hline $\begin{array}{l}\text { ASC: } \\
\text { LANDSC }\end{array}$ & $* * *-2.76991$ & 0.90245 & 0.0021 & -4.53868 & -1.00114 \\
\hline $\begin{array}{l}\text { ASC: } \\
\text { HINCOM }\end{array}$ & $* * 2.03701$ & 0.92734 & 0.028 & 0.21946 & 3.85455 \\
\hline \multicolumn{2}{|c|}{ Distns. of RPs. } & \multicolumn{4}{|c|}{ Std.Devs or limits of triangular } \\
\hline NsASC & $* * * 7.21252$ & 0.85894 & 0.0000 & 5.52902 & 8.89602 \\
\hline NsCUT1 & $* * * 1.79859$ & 0.31016 & 0.0000 & 1.19069 & 2.40649 \\
\hline NsCUT2 & *0.80319 & 0.43074 & 0.0622 & -0.04104 & 1.64741 \\
\hline NsCUT3 & $* * * 2.00062$ & 0.38462 & 0.0000 & 1.24678 & 2.75445 \\
\hline NsSIZE & $* * * 0.08519$ & 0.01988 & 0.0000 & 0.04623 & 0.12416 \\
\hline NsROUT & $* * * 1.09589$ & 0.27652 & 0.0001 & 0.55392 & 1.63786 \\
\hline NsDUR & $* * * 0.14744$ & 0.02024 & 0.0000 & 0.10778 & 0.18711 \\
\hline CsCOMP & 0.0 & \multicolumn{4}{|c|}{ (Fixed Parameter) } \\
\hline \multicolumn{2}{|c|}{ Log likelihood function } & \multicolumn{4}{|c|}{-979.34264} \\
\hline \multicolumn{2}{|l|}{ AIC } & \multicolumn{4}{|c|}{2002.7} \\
\hline \multicolumn{2}{|l|}{$\mathrm{AIC} / \mathrm{N}$} & \multicolumn{4}{|l|}{1.277} \\
\hline \multicolumn{2}{|c|}{$\mathrm{N}$ (observations) } & 1568 & & & \\
\hline \multicolumn{2}{|c|}{ Panel (individuals) } & 416 & & & \\
\hline
\end{tabular}

$* * *$ Significant at the 0.01 level.

$* *$ Significant at the 0.05 level.

*Significant at the 0.10 level.

the random variables are all significant, indicating that respondents' preferences for the variables are heterogeneous.

\subsection{Marginal WTAs}

To accept an LRVT contract, the forest owners ask on average a compensation of $€ 181.2$ per ha per year, which is equal to marginal WTA, without taking into account any specific management changes required (Table 4). This constant 'threshold value' reflects the forest owner's perceived cost of moving away from the current situation and committing themselves to the contract. In addition, the owners claim extra compensation for each restriction of a contract. An additional compensation of $€ 13.7$ per ha per year would be claimed if no regeneration cuttings were allowed, and a compensation of $€ 136.3 /$ ha/year 
Table 7

Policy scenarios and compensation variations (CV).

\begin{tabular}{|c|c|c|c|c|c|}
\hline \multirow[b]{2}{*}{ Variable } & $\begin{array}{l}\text { Scenario } \\
1\end{array}$ & $\begin{array}{l}\text { Scenario } \\
2\end{array}$ & $\begin{array}{l}\text { Scenario } \\
3\end{array}$ & $\begin{array}{l}\text { Scenario } \\
4\end{array}$ & $\begin{array}{l}\text { Scenario } \\
5\end{array}$ \\
\hline & \multicolumn{5}{|c|}{ Contract terms } \\
\hline $\begin{array}{l}\text { CUT1 ( } 0=\text { off, } \\
1=\text { on })\end{array}$ & 1 & 0 & 0 & 0 & 0 \\
\hline $\begin{array}{l}\text { CUT2 }(0=\text { off, } \\
1=\text { on })\end{array}$ & 0 & 1 & 0 & 0 & 0 \\
\hline $\begin{array}{l}\text { CUT3 (0=off, } \\
1=\text { on })\end{array}$ & 0 & 0 & 1 & 1 & 1 \\
\hline SIZE (\%) & 5 & 5 & 5 & 10 & 20 \\
\hline DUR (years) & 5 & 5 & 5 & 10 & 20 \\
\hline CV $(€ / h a / y r)$ & 191.25 & 270.88 & 456.84 & 569.58 & 795.05 \\
\hline
\end{tabular}

would be needed if all timber harvesting was prohibited. The former effect is not, however, statistically significant. Considering the areal coverage of the restrictions in owner's property, the compensation claim increases by $€ 8.4$ per percentage point per year. Accordingly, the compensations for restrictions affecting only $5 \%$ of the forest area, for example, should be $€ 42.0$ per ha per year. Interestingly, the figure for prohibiting all clear-cuttings is negative ( $€-108.5 /$ ha/year). This suggests that rather than claiming compensation, the forest owners on average considered this change as a benefit. For the establishment of new outdoor routes of $1000 \mathrm{~m}$, a compensation of $€ 16.1$ per year was estimated, but the effect is not significant.

The largest compensation claims are associated with changes in the duration of the contract. The claim of $€ 15.7$ per ha per year of contract means that the forest owner's commitment to the enhanced provision of landscape and recreational services for a 20 -year rather than a 5 -year contract would increase the required compensation from $€ 78.5$ to $€ 314.0$ per ha per year. This suggests that the forest owners are quite reluctant to accept obligations that restrict their (and their heirs') forest management for considerable periods of time.

\subsection{Individual-specific factors explaining the choice of no-contract alternative}

The analysis of preference heterogeneity was carried out by examining how respondent's background variables affect the probability to make a contract within LRVT. Seven statistically significant variables GEND, AGE, KUUS, EDUC, INHER, LANDSC, and HINCOM (Table 5) were selected for the final model after data-driven testing.

Table 6 shows results of an RPL model with interactions between ASC and individual-specific variables. The inclusion of the interaction variables affected the coefficients of main variables to some extent. In particular, the main coefficient of ASC loses its significance. Hence, the interaction variables explain comprehensively the choice of a nocontract alternative. Additionally, the coefficient of CUT1 loses its significance. On the other hand, the coefficient of CUT2 receives statistical significance, making the model more logical.

Regarding the effects of interaction variables, the term ACE:GEND is negative, indicating that male respondents are more often willing to make a contract than non-male respondents. This means that male forest owners seem to benefit more from a contract than others. The same is true regarding the interaction terms ASC:EDUC and ASC:LANDSC: Those respondents who have a degree from a university or polytechnic or whose forest property includes scenic landscapes tend to be more willing to make a contract than the rest of the respondents.

On the other hand, the coefficient of ASC:AGE is positive, suggesting that the older a respondent is, the less ready he or she is to enter a contract. The same also hold true for the interaction terms ASC:KUUS, ASC:INHER, and ASC:HINCOM. Thus, the respondents who live in Kuusamo or who have inherited the forest property they owned, or those whose net household income is less than $€ 2000$ per month, are less willing to enter a contract than others.

\subsection{Policy scenarios of different contract designs for LRVT}

To illustrate how alternative contract terms would influence forest owners' economic welfare and compensation claims, five scenarios were created. The main differences between scenarios come from the variation in the values of contract terms from low to high restrictions. The compensation variations of the scenarios were calculated by using the results shown in Tables 5 and 6 . The features of the scenarios and associated compensating variations are presented in Table 7 .

Scenarios 1-3 include the low requirements for the duration of contract ( 5 years) and the size of affected forest area (5\% of the forest area of the property), but the harvesting restrictions vary. The compensation claim is lowest in Scenario 1 ( $€ 191.25 /$ ha/year), in which clear-cutting is not allowed. The compensation claims increase as the harvest restrictions become tighter in Scenarios 2 and 3. The tighter requirements for the size of restrictions and the duration of contract further increases the compensation claims. The highest compensation claims are in Scenario 5 ( $€ 795.05 /$ ha/year), in which all timber harvesting is prohibited, the duration of the contract is 20 years, and the contract covers $20 \%$ of the forest area of the property.

\section{Discussion}

This study examined possibilities to develop new, market-based instruments targeted to improve the provision of forest amenities in a nature-based tourism area. These amenities are demanded by tourists and increasingly valued also by tourism entrepreneurs, but are neither exchanged in markets nor adequately included in the current governmental subsidy schemes targeted to forest owners (Tyrväinen et al., 2014., Mäntymaa et al., 2019). The study examined the opinions and preferences of private landowners in Kuusamo, located in northeastern Finland. It dealt with enhancing landscape and recreation values, as nature-based tourism is a significant business in the region, and investigated which types of voluntary, market-based mechanisms would be acceptable for forest owners.

In general, the landowners seemed to have a relatively positive attitude towards the suggested LRVT mechanism if economic losses were to be compensated. However, when asked in more detail from the perspective of restrictions placed on their forest holdings, the acceptability decreased, and compensation claims increased rapidly when more demanding cutting restrictions were put in place. Importantly, the landowners' preferences for LRVT were somewhat heterogeneous. Hence, some forest owners are more willing to participate than others, and forest owners value the terms of the contract in different ways. This is in line with previous research showing that today, private forest owners have diverse motivations, attitudes, and goals linked to their ownership, which are linked to societal value and demographic changes as well as decreased dependence on forest-based income (e.g. Dominguez and Shannon, 2011; Urquhart et al., 2012; Karppinen and Korhonen, 2013; Häyrinen, 2019).

Given the newness of the proposed mechanism for the landowners, a relatively high proportion of forest owners were interested in the suggested scheme and also prepared to accept various obligations. The willingness to participate was, however, strongly dependent on the amount of compensation, as well as on other terms of the contract, such as duration and harvesting restrictions. The results of policy scenarios showed that compensation claims increased when the restrictions became more severe and the duration of the contract increased. The largest marginal compensation claims were related to long contract durations and the stringent "no harvesting at all" restriction - the compensation claim for the latter being over three times higher than the claim for "no regeneration cuttings." These results were expected, as opportunity costs and financial losses increase with management restrictions and duration of contract. In addition, long duration of contract can be considered to restrict the freedom of the heirs. Similar findings have been obtained in studies on participation in voluntary biodiversity 
conservation programs and in carbon markets (e.g., Lindhjem and Mitani, 2012; Markowski-Lindsay et al., 2011; Vedel et al., 2015b).

The average compensation claim varied from $€ 191$ to $€ 795$ per ha per year, depending on the contract terms used in this study. The more stringent the contract terms, the greater the claims for compensation. Mäntymaa et al. (2018a) found that the average compensation claim was about $€ 330$ per ha per year for a 5-year LRVT contract in which clearcuttings were prohibited. Our estimate was therefore somewhat lower for the LRVT contract involving these particular terms. The compensation claims of our study are higher than the average payments made $(€ 176 /$ ha/year) for a 10 -year contract in the Finnish METSO program ten years ago (Juutinen et al., 2008), where the compensation is based on the market value of the timber and related opportunity costs (Ten years of METSO..., 2019). Currently this program is targeted to private landowners in southern Finland, where share of protected old forests is the lowest. Related to the relatively high compensation claims, we should also refer to the well-known disparity between WTP and WTA measures of environmental benefits found in a significant number of empirical studies (e.g. Coursey et al., 1987; Horowitz and McConnell, 2002). Moreover, some landowners might have behaved strategically by expressing larger WTA in order to influence the design of compensation levels than they would demand in a real-life situation (e.g. Mitchell and Carson, 2013).

From a larger-scale perspective, there are obviously questions about how the demand and supply meet each other. In striving towards cost efficiency, it is important to examine the extent to which the scenically valuable forest areas are owned by persons who are willing to join the suggested mechanism. The analysis of background variables of forest owners revealed that those owners whose forest property includes, in their opinion, scenic landscapes are more willing to accept the proposed contract. This suggests that owners are aware that their forests provide these public goods and therefore may be willing to accept the proposed new instrument. Moreover, in some cases, there may already be restrictions on forest management caused by, for example, land-use planning processes, and therefore, a new funding mechanism for amenity values would offer them an opportunity to gain monetary benefits. We found also other significant individual-specific explanatory variables for the willingness to accept. In particular, forest owners living in the Ruka-Kuusamo area are less likely to accept the contract than forest owners living outside of the area. Hence, it is important to market LRVT to forest owners living outside the region and whose forests are located in areas that are important for the Ruka-Kuusamo tourism activities when implementing the new mechanism in the future. The respondents of the survey owned larger forest holdings than on average. This needs to be taken into account when generalizing the results. This may also indicate that larger holdings offer better opportunities to provide a variety of products and services than smaller ones. As such, the response rate (35.3\%) was similar when compared to recent study by Mäntymaa et al. (2018a, 2018b) but somewhat higher than the forest owner survey by Haltia and Rämö (2017).

The preference heterogeneity caused some variation in the results of CE analysis. We first estimated the RPL model without individualspecific explanatory variables. In this case, the marginal WTA estimate for the prohibition of clear-cutting was negative, suggesting that forest owners on average would prefer this type of management change. This may be a result of the public debate, since the discussion related to needs to adapt forest management practices in order to balance nature and recreational values with wood production has been active since the renewal of Finnish Forest Law in the beginning of 2014. Our results suggest that despite the fact that clear-cutting is a standard procedure in the Kuusamo area, the respondents of this study may have negative attitudes towards it, as it is not considered appropriate for an area with high levels of tourism activity. However, forest owners' preferences for the prohibition of clear-cutting were heterogeneous, and the estimated coefficient (mean) for the prohibition of clear-cutting was not significant when individual-specific variables were included in the model. Hence,
Table A1

Estimation results of RPL model with correlations between parameters.

\begin{tabular}{|c|c|c|c|c|c|}
\hline Variable & Coefficient & Standard error & $P$ value & \multicolumn{2}{|c|}{$95 \%$ confidence interval } \\
\hline \multicolumn{6}{|c|}{ Random parameters in utility functions } \\
\hline ASC & -0.31297 & 0.51021 & 0.5396 & -1.31297 & 0.68702 \\
\hline CUT1 & -0.53755 & 0.42032 & 0.2009 & -1.36136 & 0.28626 \\
\hline CUT2 & $* *-0.95015$ & 0.42294 & 0.0247 & -1.7791 & -0.12120 \\
\hline CUT3 & $* * *-2.26366$ & 0.50532 & 0.0000 & -3.25407 & -1.27326 \\
\hline SIZE & $* * *-0.07878$ & 0.01987 & 0.0001 & -0.11772 & -0.03984 \\
\hline ROUT & $*-0.45824$ & 0.24728 & 0.0639 & -0.94289 & 0.02641 \\
\hline DUR & $* * *-0.15178$ & 0.02357 & 0.0000 & -0.19798 & -0.10557 \\
\hline COMP & $* * * 0.00744$ & 0.00082 & 0.0000 & 0.00583 & 0.00905 \\
\hline \multicolumn{6}{|c|}{ Standard deviations of parameter distributions } \\
\hline NsASC & $* * * 5.19552$ & 0.73025 & 0.0000 & 3.76426 & 6.62678 \\
\hline NsCUT1 & $* * * 2.82440$ & 0.64474 & 0.0000 & 1.56073 & 4.08808 \\
\hline NsCUT2 & $* * * 2.61483$ & 0.61335 & 0.0000 & 1.41268 & 3.81698 \\
\hline NsCUT3 & $* * * 3.48377$ & 0.54151 & 0.0000 & 2.42244 & 4.54510 \\
\hline NsSIZE & $* * * 0.07410$ & 0.01815 & 0.0000 & 0.03853 & 0.10968 \\
\hline NsROUT & $* * * 1.54780$ & 0.35072 & 0.0000 & 0.86041 & 2.23520 \\
\hline NsDUR & $* * * 0.17851$ & 0.01728 & 0.0000 & 0.14464 & 0.21237 \\
\hline CsCOMP & 0.0 & \multicolumn{4}{|c|}{ (Fixed Parameter) } \\
\hline \multicolumn{2}{|c|}{ Log likelihood function } & \multicolumn{4}{|c|}{-1442.37652} \\
\hline \multicolumn{2}{|c|}{ AIC } & \multicolumn{4}{|l|}{2956.8} \\
\hline \multicolumn{2}{|l|}{$\mathrm{AIC} / \mathrm{N}$} & \multicolumn{4}{|l|}{1.246} \\
\hline \multicolumn{2}{|c|}{$\mathrm{N}$ (observations) } & \multicolumn{4}{|l|}{2373} \\
\hline \multicolumn{2}{|c|}{ Panel (individuals) } & \multicolumn{4}{|l|}{416} \\
\hline
\end{tabular}

more credible results were obtained by explicitly explaining the preference heterogeneity with individual-specific variables in the RPL model. The changes in parameters seem partly to be related to correlations between parameters, as the results of the RPL model with correlations resembling the ones of the RPL model with interactions (see Appendix Table A1). As the correlation model may, however, be subject to a parameter ordering effect (Palma et al., 2018), we decided to keep the basic RPL model in the text.

In conclusion, it seems that there exists at least tentative acceptability among landowners in Kuusamo towards the suggested LRVT, indicating that the instrument could serve the increasing needs of the tourism activities taking place in this area. However, more uncertainty exists as to whether the "positively minded landowners" who are the suppliers of the amenity values will, in practice, accept the characteristics of the commonly agreed LRVT system and whether these owners truly can supply the demanded amenities from their own forests. Moreover, given the landowners' preference heterogeneity, there is a need to develop a PES system which is not too strictly defined. Instead, the system should offer flexibility to join the system for landowners who have their forests in important locations. For example, the restrictions applied to forest management could be tailored together with the owner and the responsible organization. Furthermore, additional compensations could be paid if some infrastructures, like parking places or skiing tracks, are built in the forests. Moreover, prioritizing areas having not only scenic but also high biodiversity values would strengthen the ecological impact of the mechanism. This would improve the acceptability of the mechanism both for tourists (Tyrväinen et al., 2014) and forest owners.

Finally, as the future mechanism needs to be cost-efficient, the choice of valuable forest sites need to be identified at the landscape level beforehand, by locating the scenic and biodiversity hotspots in the key areas used for tourism. This procedure will remarkably reduce the size of the necessary forest sites, and therefore, only a relatively small share of forest owners are required to participate in the anticipated LRVT system, designed to enhance the quality of landscapes and the environment for tourism in Kuusamo.

\section{CRediT authorship contribution statement}

Liisa Tyrväinen: Conceptualization, Funding acquisition, Methodology, Supervision, Writing - original draft, Writing - review \& editing. Erkki Mäntymaa: Conceptualization, Methodology, Data curation, 
Formal analysis, Writing - original draft. Artti Juutinen: Methodology, Writing - review \& editing. Mikko Kurttila: Writing - review \& editing. Ville Ovaskainen: Conceptualization, Methodology, Writing - review \& editing.

\section{Acknowledgements}

This paper is the result of work that was supported by the NEWFOREX project of the EU Seventh Framework Programme [grant number 243950] and the EU Horizon 2020 Framework Programme SINCERE project, grant number 773702]. Aso, funding from the Strategic Research Council (SRC) at the Academy of Finland [PALO project, grant number 312671] contributed to this research.

\section{Appendix A}

\section{Appendix B. Supplementary data}

Supplementary material related to this article can be found, in the online version, at doi:https://doi.org/10.1016/j.landusepol.2020.10 4478.

\section{References}

Aggestam, F., Pülzl, H., Sotirov, H., Winkel, G., 2017. The EU policy framework. In: Winkel, G. (Ed.), Towards a Sustainable European Forest-Based Bioeconomy Assessment and the Way Forward. What Science Can Tell Us 8. European Forest Institute, pp. 19-35. ISBN 978-952-5980-42-4 (pdf). URL: http://www.efi.int/files/a ttachments/publications/wsctu8_2017.pdf, (accessed 23 March 2019).

Bell, S., Simpson, S., Tyrväinen, L., Sievänen, T., Pröbstl, U. (Eds.), 2008. European Forest Recreation and Tourism: A Handbook. Taylor and Francis Group, London, 264 pp.

Bieling, C., 2004. Non-industrial private-forest owners: possibilities for increasing adoption of close-to-nature forest management. Eur. J. For. Res. 123, 293-303. URL https://link.springer.com/article/10.1007/s10342-004-0042-6 (accessed 23 March 2019).

Boon, T.E., Meilby, H., Thorsen, B.J., 2004. An empirically based typology of private forest owners in Denmark: improving communication between authorities and owners. Scand. J. For. Res. 19, 45-55. https://doi.org/10.1080/ 14004080410034056 (accessed 21 November 2017).

Dominguez, G., Shannon, M., 2011. A wish, a fear and a complaint: Understanding the (dis)engagement of forest owners in forest management. Eur. J. For. Res. 130, 435-450. https://doi.org/10.1007/s10342-009-0332-0 (accessed 23 March 2019).

Campbell, D., Vedel, S.E., Thorsen, B.J., Jacobsen, J.B., 2014. Heterogeneity in the WTP for recreational access: distributional aspects. J. Environ. Plan. Manag. 57, 1200-1219. https://doi.org/10.1080/09640568.2013.793173 (accessed 30 August 2019).

ChoiceMetrics, 2010. Ngene 1.0.2 the Cutting Edge in Experimental Design. User Manual \& Reference Guide. ChoiceMetrics, Sydney, $230 \mathrm{p}$.

Council Directive 92/43/EEC of 21 May 1992 on the conservation of natural habitats and of wild fauna and flora. URL: https://eur-lex.europa.eu/legal-content/EN/TXT/? uri=CELEX:31992L0043 (accessed 25 March 2019).

Council of Europe, 2012. The European Landscape Convention. URL: http://www.coe. int/t/dg4/cultureheritage/heritage/Landscape/defaulten.asp (accessed 25 March 2019).

Coursey, D.L., Hovis, J.L., Schulze, W.D., 1987. The Disparity between willingness to accept and willingness to pay measures of value. Q. J. Econ. 102, 679-690. URL: https://www.jstor.org/stable/1884223 (accessed 25 March 2019).

Facts about Ruka and Kuusamo, 2017. Facts About Ruka and Kuusamo. URL: http://www.ruka.fi/en/facts (accessed 10 August 2017).

Finnish Bioeconomy Strategy, 2014. Sustainable Growth From Bioeconomy - the Finnish Bioeconomy Strategy. Ministry of Employment and the Economy, Edita Publishing Ltd., 32 pp. URL: http://biotalous.fi/wp-content/uploads/2014/08/The_Finnish_Bi oeconomy_Strategy_110620141.pdf (accessed 1 March 2018).

Finnish statistical yearbook of forestry, 2014. Finnish Statistical Yearbook of Forestry 2014. Official Statistics of Finland, Finnish Forest Research Institute, Tammerprint Oy, Tampere, 428 p. http://stat.luke.fi/sites/default/files/vsk14_koko_julkaisu.pdf (accessed 10 January 2018).

Fredman, P., Tyrväinen, L., 2010. Introduction. In: Fredman, P., Tyrväinen, L. (Eds.), Frontiers in Nature-Based Tourism. Scandinavian Journal of Hospitality and Tourism, 10, 177-189.

Gundersen, V., Frivold, L., 2008. Public preferences for forest structures: a review of quantitative surveys from Finland, Norway and Sweden. Urb. For. Urb. Green. 7 241-258. URL: https://doi.org/10.1016/j.ufug.2008.05.001 (accessed 27 March 201).
Haltia, E., Rämö, A.-K., 2017. Why Do the Economic Opportunities of Forests Remain Untapped? - Forest Owner Survey Results. PTT Reports 256, 181 p. ISBN 978-952224-196-2 (PDF), ISSN 1796-4776 (PDF).

Hanemann, W.M., 1982. Applied Welfare Analysis With Qualitative Response Models. University of California, Berkeley. Working Paper 241, 28 p., URL: https ://cloudfront.escholarship.org/dist/prd/content/qt7982fok8/qt7982f0k8.pdf (accessed 27 March 2019).

Hänninen, H., Karppinen, H., Leppänen, J., 2011. Finnish Forest Owner 2010. (Suomalainen metsänomistaja 2010. In Finnish). Working Papers of the Finnish Forest Research Institute, 208. 94 p. http://www.metla.fi/julkaisut/workingpapers/ 2011/mwp208.htm (accessed 4 October 2017).

Hänninen, H., Leppänen, J., Ovaskainen, V., Uusivuori, J., Viitala, E.J., 2017. Metsätalouden uusi kannustinjärjestelmä - Teoriaa, käytäntöjä ja ehdotukset (New incentive system of forestry - Theory, practices and suggestions, in Finnish). Luonnonvara- ja biotalouden tutkimus, 5/2017. 93 p. https://jukuri.luke.fi/bitstre am/handle/10024/538067/luke-luobio_5_2017.pdf?sequence $=1$ (accessed 22 January 2018).

Häyrinen, L., Mattila, O., Berghäll, S., Närhi, M., Toppinen, A., 2017. Exploring the future use of forests: perceptions from non-industrial private forest owners in Finland. Scand. J. For. Res. 32, 327-337. https://doi.org/10.1080/ 02827581.2016.1227472 (accessed 19 June 2018).

Häyrinen, L., 2019. Finnish Forest Owner Objectives As Indicators for a Diversifying Use of Forests on the Road to a Bioeconomy. https://doi.org/10.14214/df.280.

Horne, P., 2006. Forest owners' acceptance of incentive based policy instruments in forest biodiversity conservation - a choice experiment based approach. Silva Fenn. 40, 169-178. URL: http://jukuri.luke.fi/bitstream/handle/10024/532600/Horne. pdf? sequence $=1$ (accessed 27 March 2019).

Horowitz, J.K., McConnell, K.E., 2002. A review of WTA/WTP studies. J. Environ. Econ. Manage. 44, 426-447. https://doi.org/10.1006/jeem.2001.1215 (accessed 25 March 2019).

Hynes, S., Hanley, N., Scarpa, R., 2008. Effects on welfare measures of alternative means of accounting for preference heterogeneity in recreational demand models. Am. J. Agric. Econ. 90, 1011-1027. URL: https://doi.org/10.1111/j.1467-8276.2008.0 1148.x (accessed 28 March 2019).

Jack, B.K., Kousky, C., Sims, K.R.E., 2008. Designing payments for ecosystem services: lessons from previous experience with incentive-based mechanisms. PNAS 105, 9465-9470. URL https://doi.org/10.1073/pnas.0705503104 (accessed 4 September 2019).

Juutinen, A., Kosenius, A.-K., Ovaskainen, V., 2014. Estimating the benefits of recreation-oriented management in state-owned commercial forests in Finland: a choice experiment. J. For. Econ. 20, 396-412. URL: https://doi.org/10.1016/j.jfe. 2014.10.003 (accessed 25 March 2019).

Juutinen, A., Mäntymaa, E., Ollikainen, M., 2013. Landowners' conservation motives and the size of information rents in environmental bidding systems. J. For. Econ. 19, $128-148$.

Juutinen, A., Ollikainen, M., 2010. Conservation contracts for forest biodiversity. Theory and experience from Finland. For. Sci. 56, 201-211.

Juutinen, A., Mäntymaa, E., Mönkkönen, M., Svento, R., 2008. Voluntary agreements in protecting privately owned forests in Finland - to buy or to lease? For. Policy Econ. 10, 230-239. URL: https://doi.org/10.1016/j.forpol.2007.10.005 (accessed 25 March 2019).

Kaltenborn, B.P., Haaland, H., Sandell, K., 2001. The public right of access - some challenges to sustainable tourism development in Scandinavia. J. Sustain. Tour. 9, 417-433. https://doi.org/10.1080/09669580108667412 (accessed 22 December 2018).

Karppinen, H., Korhonen, M., 2013. Do forest owners share the public's values? An application of Schwartz's value theory. Silva Fenn. 47, 1-16. URL: http://www silvafennica.fi/article/894 (accessed 25 March 2019).

Kuuluvainen, J., Karppinen, H., Ovaskainen, V., 1996. Landowner objectives and nonindustrial private timber supply. For. Sci. 42, 300-309. URL: https://doi.org/1 0.1093/forestscience/42.3.300 (accessed 25 March 2019).

Ten years of METSO, 2019. An Interim Review of the First Decade of the Forest Biodiversity Programme for Southern Finland, 2019. Publications of the Ministry of the Environment, 4. 978-952-361-003-3.

Leppänen, J., 2010. Finnish family forest owner 2010 survey. Scandinavian Forest Economics 43, 184-195. URL: https://ageconsearch.umn.edu/record/199260/ (accessed 25 March 2019).

Lindhjem, H., Mitani, Y., 2012. Forest owners' willingness to accept compensation for voluntary conservation: a contingent valuation approach. J. For. Econ. 18, 290-302. URL: https://doi.org/10.1016/j.jfe.2012.06.004 (accessed 26 March 2019).

Majumdar, I., Teeter, L., Butler, B., 2008. Characterizing family forest owners: a cluster analysis approach. For. Sci. 54, 176-184. URL: https://doi.org/10.1093/forestscie nce/54.2.176 (accessed 26 March 2019).

Mäntymaa, E., Juutinen, A., Mönkkönen, M., Svento, R., 2009. Participation and compensation claims in voluntary forest conservation: a case of privately owned forests in Finland. For. Policy Econ. 11, 498-507. URL: https://doi.org/10.1016/j. forpol.2009.05.007 (accessed 26 March 2019).

Mäntymaa, E., Juutinen, A., Tyrväinen, L., Karhu, J., Kurttila, M., 2018a. Participation and compensation claims in voluntary forest landscape conservation: the case of the Ruka-Kuusamo tourism area, Finland. J. For. Econ. 33, 14-24. URL: https://doi. org/10.1016/j.jfe.2018.09.003 (accessed 26 March 2019).

Mäntymaa, E., Ovaskainen, V., Juutinen, A., Tyrväinen, L., 2018b. Integrating naturebased tourism and forestry in private lands under heterogeneous visitor preferences for forest attributes. J. Environ. Plan. Manag. 61, 724-746. https://doi.org/ 10.1080/09640568.2017.1333408 (accessed 26 March 2019). 
Mäntymaa, E., Tyrväinen, L., Juutinen, A., Kurttila, M., 2019. Importance of Forest Landscape Quality for Companies Operating in Nature Tourism Areas. Submitted manuscript, $18 \mathrm{pp}$.

Margaryan, L., 2016. Nature as a commercial setting: the case of nature-based tourism providers in Sweden. Curr. Issues Tour. 21, 1-19. URL: https://doi.org/10.1080/13 683500.2016.1232378 (accessed 26 March 2019).

Markowski-Lindsay, M., Stevens, T., Kitteredge, D., Butler, B., Catanzaro, P., Dickinson, B., 2011. Barriers to Massachusetts forest landowner participation in carbon markets. Ecol. Econ. 71, 180-190. URL: https://doi.org/10.1016/j.ecole con.2011.08.027 (accessed 26 March 2019).

Millennium Ecosystem Assessment, 2005. Ecosystems and Human Well-Being: Synthesis. Island Press, Washington, DC, 64 p., URL: http://www.bioquest.org/wp-content/ blogs.dir/files/2009/06/ecosystems-and-health.pdf (accessed 26 March 2019).

Mitchell, R.C., Carson, R.T., 2013. Using Surveys to Value Public Goods. The Contingent Valuation Method. Resources for the Future, New York and London, 484 p., DOI: https://doi.org/10.4324/9781315060569 (accessed 27 March 2019).

National Forest Inventory 9, 2016. VMI9:N Kunnittaiset Metsävarat 2016 ( $9^{\text {th }}$ National Inventory of Forest Resources, Municipal Forest Resources, in Finnish) (accessed 22 January 2018). http://www.metla.fi/cgi-bin/tilasto/vmi/vmi.cgi?VMI9.

Ovaskainen, V., Abildtrup, J., Mäntymaa, E., Vedel, S.E., Thorsen, B.J., 2014. The stated preference approach to costs of provision. In: Thorsen, B.J., Mavsar, R., Tyrväinen, L., Prokofieva, I., Stenger, A. (Eds.), The Provision of Forest Ecosystem Services, Volume II: Assessing Costs of Provision and Designing Economic Instruments for Ecosystem Services. What Science Can Tell Us 5. European Forest Institute, Joensuu, pp. 50-57 (accessed 22 January 2018). http://www.efi.int/ files/attachments/publications/efi wsctu 5 vol-2 en net.pdf.

Palma, M.A., Vedenov, D.V., Bessler, D., 2018. The order of variables, simulation noise, and accuracy of mixed logit estimates. Empir. Econ. 1-35. URL: https://doi.org/10. 1007/s00181-018-1609-2 (accessed 25 March 2019).

Roadmap for tourism, 2015. Yhdessä enemmän - kasvua ja uudistumista Suomen matkailuun 2015-2025 (in Finnish, summary in English). Ministry of Employment and the Economy reports 4/2015, 68 pp., URL: http://urn.fi/URN:ISBN:978-952 227-938-5 (accessed 22 January 2018).

Sandell, K., Fredman, P., 2010. The right of public access - opportunity or obstacle for nature tourism in Sweden? Scand. J. Hosp. Tour. 10, 291-309. https://doi.org/ 10.1080/15022250.2010.502366 (accessed 25 March 2019).

Swedish Research and Innovation Strategy, 2012. Swedish Research and Innovation Strategy for a Bio-based Economy. Formas, The Swedish Research Council for Environment, Agricultural Sciences and Spatial Planning, Report: R3:2012, 36 pp., URL: http://www.formas.se/PageFiles/5074/Strategy_Biobased_Ekonomy_hela.pdf (accessed 25 March 2019).

Thorsen, B.J., Mavsar, R., Tyrväinen, L., Prokofieva, I., Stenger, A. (Eds.), 2014. The Provision of Forest Ecosystem Services. Volume II: Assessing Cost of Provision and Designing Economic Instruments for Ecosystem Services. European Forest Institute,
Joensuu. What science can tell us 588 p., ISBN 978-952-5980-15-8, ISBN 978-9525980-14-1 [pdf], URL: http://www.efi.int/files/attachments/publications/efi_wsctu 5_vol-2_en_net.pdf (accessed 25 March 2019).

Tikkanen, J., Hokajärvi, R., Hujala, T., Kurttila, M., 2017. Ex ante evaluation of a PES system: safeguarding recreational environments for nature-based tourism. J. Rural Stud. 52, 42-55. URL: https://doi.org/10.1016/j.jrurstud.2017.03.011 (accessed 27 March 2019).

Train, K., 2009. Discrete Choice Methods With Simulation, second ed. Cambridge University Press, Cambridge.

Tyrväinen, L., Buchecker, M., Vuletic, D., Degenhart, B., 2008. Evaluating the economic and social benefits of forest recreation and nature tourism. In: Bell, S., Simpson, S., Tyrväinen, L., Sievänen, T., Pröbstl, U. (Eds.), European Forest Recreation and Tourism: A Handbook. Taylor and Francis Group Plc., London, pp. 35-64.

Tyrväinen, L., Mäntymaa, E., Ovaskainen, V., 2014. Demand for enhanced forest amenities in private lands: the case of Ruka-Kuusamo tourism area, Finland. Forest Policy and Economic 47, 4-13. URL: https://doi.org/10.1016/j.forpol.2013.05.007 (accessed 22 January 2018).

Tyrväinen, L., Silvennoinen, H., Hallikainen, V., 2017. Effect of the season and forest management on the visual quality of the nature-based tourism environment: a case from Finnish Lapland. Scand. J. For. Res. 32, 349-359. URL: https://doi.org/10.1 080/02827581.2016.1241892 (accessed 15 February 2018).

Urquhart, J., Courtney, P., 2011. Seeing the owner behind the trees: a typology of smallscale private woodland owners in England. For. Policy Econ. 13, 535-544. URL: https://doi.org/10.1016/j.forpol.2011.05.010 (accessed 27 March 2019).

Urquhart, J., Courtney, P., Slee, B., 2012. Private woodland owners' perspectives on multifunctionality in English woodlands. J. Rural Stud. 28, 95-106. URL: https:// doi.org/10.1016/j.jrurstud.2011.08.006 (accessed 22 March 2019).

Valkeapää, A., Karppinen, H., 2013. Citizens' view of legitimacy in the context of Finnish forest policy. For. Policy Econ. 28, 52-59. URL: https://doi.org/10.1016/j.forpol.20 13.01.004 (accessed 22 March 2019).

Vedel, S.E., Jacobsen, J.B., Thorsen, B.J., 2015a. Forest owners' willingness to accept contracts for ecosystem service provision is sensitive to additionality. Ecol. Econ. 113, 15-24. URL: https://doi.org/10.1016/j.ecolecon.2015.02.014 (accessed 27 March 2019).

Vedel, S.E., Jacobsen, J.B., Thorsen, B.J., 2015b. Contracts for afforestation and the role of monitoring for landowners' willingness to accept. For. Policy Econ. 51, 29-37. https://doi.org/10.1016/j.forpol.2014.11.007 (accessed 3 September2019).

Winkel, G. (Ed.), 2017. Towards a Sustainable European Forest-Based Bioeconomy Assessment and the Way Forward. What Science Can Tell Us 8. European Forest Institute, 162 p. ISBN 978-952-5980-42-4 (pdf), (accessed 20 March 2019).

Wunder, S., 2007. The efficiency of payments for environmental services in tropical conservation. Conserv. Biol. 21, 48-58. https://doi.org/10.1111/j.15231739.2006.00559.x (accessed 22 March 2019). 